\title{
The Need for Adolescent Mental Health Intervention in Primary Health Care
}

\author{
Susan Fitriyana, ${ }^{1}$ Hilmi Sulaiman Rathomi, ${ }^{1}$ Sara Shafira ${ }^{2}$ \\ ${ }^{1}$ Department of Public Health, Faculty of Medicine, Universitas Islam Bandung, Bandung, Indonesia, \\ ${ }^{2}$ Medical Undergraduate Study Program, Faculty of Medicine, Universitas Islam Bandung, Bandung
}

\begin{abstract}
Mental health problems in adolescents became a global concern. About 10-20\% of children and adolescents worldwide experience mental health problems, but only about $10 \%$ get medical attention. This study aims to perform an initial screening of adolescent mental health in Bandung, especially adolescents at school age, to get the magnitude of the problem of mental health in adolescents. This research was a cross-sectional study conducted in Bandung. Data collected in December 2018. The study used consecutive sampling to recruit 140 students from junior and senior high schools. The instrument used was the strength and difficulties questionnaire (SDQ) YR1 version, which was filled independently by respondents. Data were analyzed using STATA 13. The results of this study were that the prevalence of mental health problems in adolescents was $21 \%$. The highest aspect was emotional (28\%) and conducted problems (21\%). There was a significant different male versus female in emotional and conduction problems. In conclusion, the magnitude of the adolescent's mental health problems in Bandung was enormous; thus, interventions at the primary care level and partnership with another sector needed.
\end{abstract}

Key words: Adolescent, mental health, primary health care

\section{Perlu Intervensi Kesehatan Mental Remaja di Pelayanan Kesehatan Primer}

\begin{abstract}
Abstrak
Masalah kesehatan mental pada remaja telah menjadi perhatian dunia. Sekitar $10-20 \%$ anak dan remaja di seluruh dunia mengalami masalah kesehatan mental, tetapi hanya 10\% yang mendapatkan pelayanan kesehatan. Tujuan penelitian ini melakukan penapisan awal besaran masalah kesehatan mental pada remaja usia sekolah di Kabupaten Bandung. Penelitian ini merupakan penelitian potong lintang yang dilakukan di Kabupaten Bandung. Data dikumpulkan pada bulan Desember 2018 menggunakan consecutive sampling dengan melibatkan 140 siswa SMP dan SMA. Instrumen yang digunakan adalah strength and difficulties questionaire (SDQ) YR1 version yang diisi oleh responden. Data dianalisis menggunakan STATA 13. Hasil penelitian didapatkan prevalensi masalah kesehatan mental pada remaja adalah 21\%. Aspek penilaian tertinggi berada pada masalah emosional (28\%) dan conducting problem (21\%). Terdapat perbedaan nilai yang siginifikan untuk aspek emosinal dan conduct problem antara kelompok laki-laki dan perempuan. Simpulan, masalah kesehatan mental remaja di Kabupaten Bandung sangat besar sehingga dibutuhkan penanganan kesehatan mental remaja di tingkat pelayanan kesehatan primer dan kerja sama dengan sektor lain.
\end{abstract}

Kata kunci: Kesehatan mental, pelayanan kesehatan primer, remaja 


\section{Introduction}

Mental health problems in adolescents became a global concern. The World Health Organization (WHO) estimates that 150 million people worldwide suffered from depression, 25 million people have schizophrenia, and around 20\% occurred in adolescents. Globally, suicide ranks number three among causes of death during adolescence, and depression is the top cause of illness and disability. ${ }^{1,2}$

About $10-20 \%$ of children and adolescents worldwide experience mental health problems, but only about $10 \%$ get medical attention. Lack of health services for children and adolescents mainly occurs in low-income and middle-income countries (LMIC) due to lack of government policy, lack of funding and death of trained medical personnel. ${ }^{3}$

According to the Basic Health Research (Riskesdas) 2018, 15-24 years experienced depression as much as $6.4 \%$ and mentalemotional disorders as much as $10 \%$. From all the total depressed only about $9 \%$ get medical treatment. ${ }^{4}$

World Health Organization defined mental health as a state of well-being in which every individual realizes his or her potential, can cope with the normal stresses of life, can work productively and helpfully, and can contribute community. ${ }^{5}$ Mental health disorder is a term that covers a broad range of diseases that can affect personality, thought processes, or social interactions. At a young age, mental health problems can result in health-related disability and havelong-term adverse effects on personallife, social, and productivity. Mental health problems at an early age can interfere with educational and career performance in adulthood. If the problem not handled correctly, it will make the problem even more prominent. Early recognizing mental health problems can prevent health problems in adolescents..$^{3,6}$

This study aimed to perform an initial screening of adolescents in Bandung regency, especially in adolescents at school age, to get the magnitude of the problem. The results of this study had presented at the $5^{\text {th }}$ Asean Regional Primary Care Conference in Malaysia.

\section{Methods}

This research is a cross-sectional study conducted in Bandung regency. Data collected in December 2018. The sample of this study used consecutive sampling involving 140 students of junior high schools and senior high schools. This study has used a questionnaire (paper-based) distributed to all respondents.

The instrument used in this study was the strength and difficulties questionnaire (SDQ) YR1 version, which filled by respondents independently. SDQ is a rating scale to screen emotional and behavioral problems in children and adolescents aged 4-16 years. SDQ is also a tool to measure the risk of mental disorders in children and adolescents. SDQ assesses five aspects: emotional problems, conduct problems, hyperactivity, peer problems, and prosocial behavior. Prosocial behavior determines the strength of the respondent. Each aspect represented by five questions that distributed randomly. ${ }^{7-10}$ Table 1 used to yield of the assessment on SDQ.

The results of the questionnaire were given scoring and divided into normal and abnormal (if the score of each aspect was high, except the prosocial behavior score must be low) categories. The calculation of normal and abnormal proportions made and compared between male and female sexes. Data is processed and analyzed using STATA 13.

The study protocol had approved by the Health Research Ethics Committee of the Faculty of Medicine, Universitas Islam Bandung.

\section{Results}

Respondents are junior and senior high school students in Bandung regency, ranging from 11 to 17 years old, amounting to 140 students. Table 2 showed the characteristics of respondents in this study.

In Table 2, respondents were mostly female, with an age range of 15 to 17 years olds. The age of respondents is in the adolescent category.

The five aspects of SDQ divided into two categories, normal and abnormal, as shown in Figure 1. Assessments of at least one aspect of SDQ indicate that 50\% experience emotional and behavioral problems, while evaluations of all aspects of SDQ suggest that 21\% experience emotional and behavioral issues.

Figure 2 showed the proportions of the assessment in each aspect of SDQ which the highest proportion of assessment is emotional 
Table 1 Strength and Difficulties Questionnaire

\begin{tabular}{lccc}
\hline Self-completed Versions & $\begin{array}{c}\text { Close to Average } \\
\text { Score }^{*}\end{array}$ & $\begin{array}{c}\text { Slightly Raised } \\
\text { Score }^{* * *}\end{array}$ & High Score $^{* * *}$ \\
\hline Total difficulties score & $0-15$ & $16-19$ & $20-40$ \\
Emotional symptoms score & $0-5$ & 6 & $7-10$ \\
Conduct problem score & $0-3$ & 4 & $5-10$ \\
Hyperactivity score & $0-5$ & 6 & $7-10$ \\
Peer problem score & $0-3$ & $4-5$ & $6-10$ \\
Prosocial behavior score & $6-10$ & 5 & $0-4$ \\
\hline N & & 5
\end{tabular}

Note: "this score is close to average-clinically significant problems in this area are unlikely; *"this score is slightly raised, which may reflect clinically significant problems; ${ }^{* * *}$ this score is high-there is a substantial risk of clinically significant problems in this area

(28\%) and conduct problem (21\%).

Each aspect of SDQ compared by gender. Figure 3 showed the distribution of each element of SDQ by gender. This study revealed significantly different than the highest SDQ aspect in the female gender is the emotional problem (37\%), while the conducting problem in the male gender (30\%, $\mathrm{p}<0.05)$.

\section{Discussion}

Knowledge about the prevalence of mental health problems in adolescents is the first step to determine the magnitude of the problem. The prevalence of adolescent mental health problems in this study was $21 \%$. This value is higher than the global prevalence (Kieling et al., ${ }^{3}$ 10-20\%) and Malaysia (Gomez and Suhaimi, ${ }^{11} 5 \%$ with $10 \%$ in borderline) and in previous studies (Atilola et al., $\left.{ }^{12} 7.9 \%\right)$.

Research in Kieling et al. ${ }^{3}$ mentions that the majority of mental health problems in adolescents are in low-income and middleincome countries (LMIC). Based on this research the life-long risk factors that cause mental health problems in adolescents at LMIC consist of genetic background, physical health problems

Table 2 Characteristics of Respondents

\begin{tabular}{lrc}
\hline Characteristics & $\mathbf{n = 1 4 0}$ & $\mathbf{\%}$ \\
\hline Gender & & \\
Male & 57 & 41 \\
Female & 83 & 59 \\
Age (years) & & \\
$11-14$ & 109 & 78 \\
$15-17$ & 31 & 22 \\
\hline
\end{tabular}

and nutritional status in children, physical and psychological health of parents, loss of parents or being orphaned, raised in institutions, deficiency psychosocial environment and educated, exposed to dangerous substances and poisons, violence or being in a conflict or war zone, being in a disaster area and experiencing abuse or neglect. ${ }^{3,13}$

Risk factors for mental health problems in children and adolescents are multifactorial and run chronically to cause clinical manifestations. Risk factors can arise in every phase of a child's life. During the preconception period, risk factors consist of teenage pregnancy, unwanted pregnancy, inadequate birth spacing, and parenteral consanguinity. ${ }^{3,13}$ During perinatal risk factors that arise are insufficient prenatal care, high-risk pregnancy, adaptation to pregnancy or the birth of an inadequate baby and maternal death after giving birth. ${ }^{3}$

Risk factors that arise during infancy or early childhood are that children cannot achieve optimal brain and emotional development in this phase. Stunting, inadequate stimulation, poor care, and home stimulation, iodine and iron deficiency, exposure to violence, HIV/ AIDS, malaria, intrauterine growth retardation, or exposure to heavy metals causes inadequate brain and emotional development. ${ }^{3,14-16}$ Risk factors that arise at school age (from 5 years to 18 years) are obesity, academic difficulties, school bullying, family dysfunction, physical and sexual abuse, smoking, drinking alcohol and drug use, pathological internet use, and pregnancy in adolescence. ${ }^{3,17-19}$

The highest proportion of scores in this study were in the emotional aspects (28\%) and peer problems (21\%), while the most top scores in the Gomez study were peer problems and in 

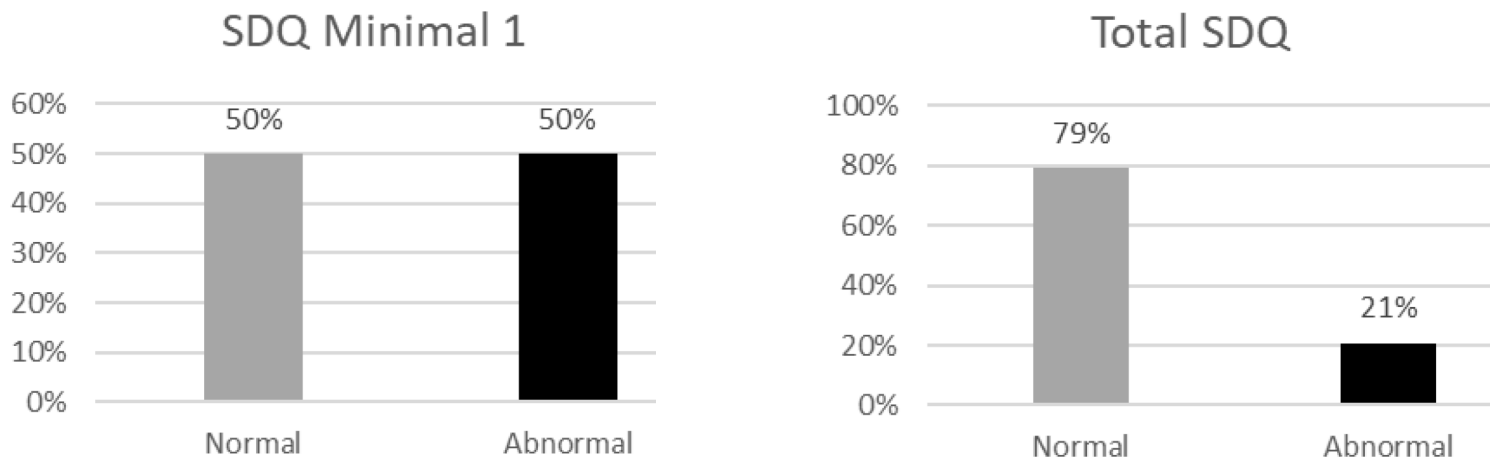

Figure 1 Substantial Risk-based SDQ Total Score versus Minimal 1 Aspect

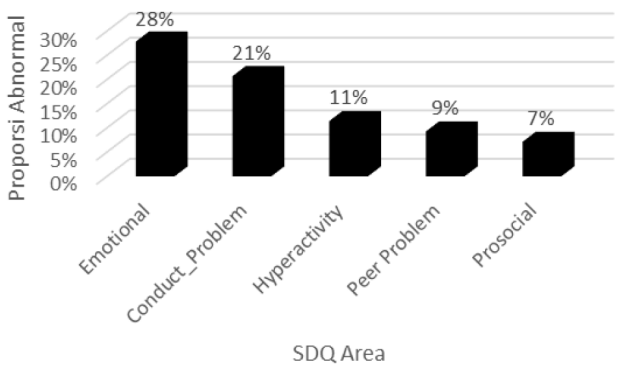

Figure 2 Proportion of Respondent with Substantial Risk per Area

the Arshat research were peer problems and prosocial aspects. ${ }^{11,20}$

Arshat $^{20}$ states that family strength influences emotional and behavioral. Teenagers who live in a family environment with open communication have better mental health research conducted in South Africa ${ }^{21}$ shows that family disadvantage (caregiver AIDS illness and poverty) has an indirect effect on adolescent mental health. In family, disadvantage increases abusive parenting and mental health distress caregiver, which increases the risk of mental health in adolescents. Research at Atilola et al..$^{12}$ states that adolescents who have mental health problems are teenagers who live with single parents or other non-parent caregivers and come from families with lower family affluence scale (FAS) scores. FAS is a selfreport questionnaire that provides information about familial wealth indicators using four parameters, including family car ownership, adolescent's bedroom, family ownership of a computer, and family holiday in the previous 12 months.

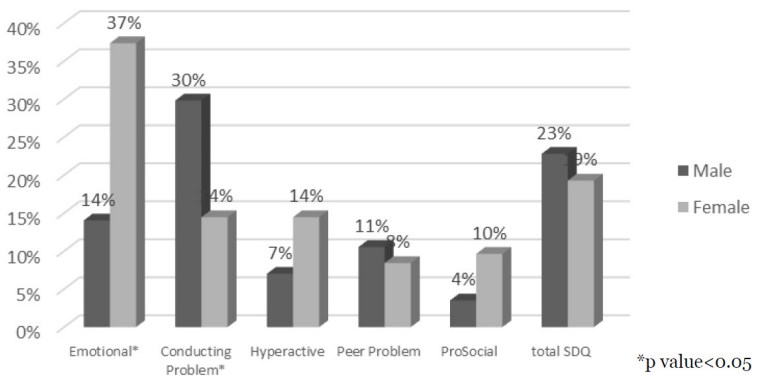

Figure 3 Distribution of SDQ based on Gender

The United Nations International Children's Fund (UNICEF) defines the family as an essential component to form a residential environment that ensures that the children living in it protected from all forms of adverse social conditions. The family had the most significant influence on children's welfare so that all factors affecting the family could disrupt the welfare of children. Problems that are in the family can cause health problems in adolescents. ${ }^{12}$

Significant value differences between the sexes of male and female are in the emotional aspects and conduct problems. The highest issue in males is the conduction problem, and the most upper item in females is an emotional problem. Women tend to experience more emotional issues because several factors such as genes, hormones (estrogen and progesterone) and also brain structure. ${ }^{22}$ This research is in line with previous research conducted by Atilola et al. ${ }^{12}$ and other studies that emotional and conduct problems are the most significant burden of mental health among children. 
Mental health problems at a young age can result in health-related disability and have longterm adverse effects on personal life, social, and productivity. Early treatment and prevention in primary health care facilities can prevent mental health problems later in life and improve individual well-being and productivity. ${ }^{3}$

Islam believes that health, including mental health, is a fundamental human right. From an Islamic perspective, health determinants consist of faith and worship, behavior, environment, social, genetic, and health services. Islam views the efforts of health services can help prevent disease and restore health conditions. ${ }^{23}$

Primary health care can help prevent mental health problems in every phase of a child's life. Primary health care has a program of antenatal care during the preconception period, giving birth to trained health workers and postnatal care to maintain maternal health during pregnancy, during childbirth, and after delivery. Family planning programs in primary health services can control birth spacing.

During the early childhood, primary health care can prevent mental health problems by optimizing the role of pos pelayanan terpadu (posyandu) by involving cadres to deal with the causes of mental health problems in the early phase of children's lives. Posyandu is a form of community-based health unit formed by the community and has the primary function to help the community, especially mothers and children under five years of age, to maintain and improve their health. ${ }^{24}$

Mental health problems are related to malnutrition in early childhood. One of the posyandu programs that can be adapted to prevent mental health problems in adolescents is by improving nutrition through the administration of $\mathrm{Fe}$ tablets. The provision of vitamin $\mathrm{Fe}$ to prevent iron-deficiency anemia improves behavior and temperament for children aged 12 months. Children from 6 months to 2 years are susceptible to nutritional deficiencies, especially iron, iodine, folic acid, vitamin A, and zinc. The provision of complementary foods at posyandu can help to prevent nutrient deficiencies in children. ${ }^{3,24}$

During the school-aged period, primary health services play a role in screening mental health problems using standardized instruments. This screening program can be carried out periodically by involving the roles of parents and schools. Early diagnosis and prompt treatment prevent the emergence of long-term adverse effects on adolescent life. Many adolescents with mental disorders do not get adequate medical treatment because of a lack of funds, lack of family knowledge about mental illness symptoms, and unfortunate community stigma about people with mental disorders. ${ }^{5}$ Optimizing the role of cadres is needed to educate the public so able to increase public knowledge and eliminate the unfortunate stigma of people with mental disorders. Education intervention improved a positive impact on understanding so that it can stimulate perception change and behavior change. ${ }^{5,24}$ This change is expected to eliminate barriers for people, especially adolescent, with mental disorders to get the right treatment.

Mental health risk factors consist of various aspects such as family conditions, informal education from parents, and formal education from schools, nutritional status. So, the handling and prevention of mental health need to involve other sectors such as education and social. Early stimulation interventions, integrating nutrition, health, and stimulation programs, attendance at high quality pre-school, and conditional transfers to families have proven to be beneficial for improving children's mental health. ${ }^{3}$

Support from family and school environment is essential to prevent mental health in adolescents. Research conducted by Stadler et al. ${ }^{25}$ on students who experienced peer victimization in the school environment stated that adolescents, both boys, and girls, who received support from parents and good schools, had a lower risk of experiencing mental health problems.

A limitation of this study is that the sample was taken in one area and only looked at age and sex factors. We recommend conducting screening in a larger area by including socio-economic aspects, the nutritional status of children, demographic conditions of parents or caregivers, and family functions.

\section{Conclusion}

This study concludes that the magnitude of the adolescents' mental health problems in Bandung was enormous. We recommend further screening with broader coverage. Intervention at the primary care level and partnership with another sector (education, social) are needed. 


\section{Conflict of Interest}

The authors declare no conflict of interest.

\section{Acknowledgments}

We acknowledge the Faculty of Medicine Universitas Islam Bandung and all junior and senior high schools who participated in the study.

\section{References}

1. World Health Organization. Health for the world's adolescents: a second chance in the second decade: summary [Internet]. Geneva, Switzerland: World Health Organization; 2014 [cited 2020 July 8]. Available from: https://www.who.int/docs/default-source/ substance-use/1612-mncah-hwa-executivesummary.pdf.

2. Department of Economic and Social Affairs, United Nations. Mental health matters: social inclusion of youth with mental health conditions [Internet]. New York: United Nations; 2014 [cited 2020 July 8]. Available from: $\quad$ http://www.un.org/esa/socdev/ documents/youth/youth-mental-health.pdf.

3. Kieling C, Baker-Henningham HB, Belfer M, Conti G, Ertem I, Omigbodun O, et al. Child and adolescent mental health worldwide: evidence for action. Lancet. 2011;378(9801):1515-25.

4. Badan Penelitian dan Pengembangan Kesehatan, Kementerian Kesehatan Republik Indonesia. Laporan Nasional Riskesdas 2018. Jakarta: Lembaga Penerbit Badan Penelitian dan Pengembangan Kesehatan; 2019.

5. Faidah NC, Respati T, Fitriyana S. Persepsi siswa SMA Negeri di Kota Bandung terhadap individu yang memiliki gangguan kesehatan jiwa. Prosiding Pendidikan Dokter. 2017;3(1):215-21.

6. Ayu IM, Respati T, Susanti Y. Preschoolers' mental health status based on their mobile gadget usage. J Phys Conf Ser. 2020;1469:012054.

7. Di Riso D, Salcuni S, Chessa D, Raudino A, Lis A, Altoe G. The strengths and difficulties questionnaire (SDQ). Early evidence of its reliability and validity in a community sample of Italian children. Pers Individ Dif. 2010;49(6):570-5.

8. Goodman A, Lamping DL, Ploubidis GB.
When to use broader internalising and externalising subscales instead of the hypothesised five subscales on the strengths and difficulties questionnaire (SDQ): data from British parents, teachers and children. $J$ Abnorm Child Psychol. 2010;38(8):1179-91.

9. Stone LL, Otten R, Engels RCME, Vermulst AA, Janssens JMAM. Psychometric properties of the parent and teacher version of the strengths and difficulties questionnaire for 4- to 12-year-olds: a review. Clin Child Fam Psychol Rev. 2010;13(3):254-74.

10. He JP, Burstein M, Schmitz A, Merikangas KR. The strengths and difficulties questionnaire (SDQ): the factor structure and scale validation in U.S. adolescents. $J$ Abnorm Child Psychol. 2013;41(4):583-95.

11. Gomez R, Suhaimi AF. Incidence rates of emotional and behavioral problems in Malaysian children as measured by parent ratings of the strengths and difficulties questionnaire. Asian J Psychiatr. 2013;6(6):528-31.

12. Atilola O, Balhara YPS, Stevanovic D, Avicenna M, Kandemir H. Self-reported mental health problems among adolescents in developing countries: results from international pilot sample. J Dev Behav Pediatr. 2013;34(2):129-37.

13. Benjet C. Childhood adversities of populations living in low-income countries: prevalence, characteristics, and mental health consequences. Curr Opin Psychiatry. 2010;23(4):356-62.

14. Rodriguez JDM, da Silva AAM, Bettiol H, Barbieri MA, Rona RJ. The impact of perinatal and socioeconomic factors on mental health problems of children from a poor Brazilian city: a longitudinal study. Soc Psychiatry Psychiatr Epidemiol. 2011;46(5):381-91.

15. Zulfa A, Hendryanny E, Garna H, Rathomi HS, Suryani YD. Hubungan riwayat kejang demam dengan gangguan perkembangan anak di RSUD Al-Ihsan Bandung. Prosiding Pendidikan Dokter. 2018;4(1):306-13.

16. Ulfah E, Rahayuningsih SE, Herman $\mathrm{H}$, Susiarno H, Gurnida DA, Gamayani U, et al. Asuhan nutrisi dan stimulasi dengan status pertumbuhan dan perkembangan balita usia 12-36 bulan. GMHC. 2018;6(1):12-20.

17. Rothon C, Head J, Klineberg E, Stansfeld S. Can social support protect bullied adolescents from adverse outcomes? A 
prospective study on the effects of bullying on the educational achievement and mental health of adolescents at secondary schools in East London. J Adolesc. 2011;34(3):579-88.

18. Marshall JE. Adolescent alcohol use: risks and consequences. Alcohol Alcohol. 2014;49(2):160-4.

19. Lee S, Guo WJ, Tsang A, He YL, Huang YQ, Zhang MY, et al. The prevalence of family childhood adversities and their association with first onset of DSM-IV disorders in metropolitan China. Psychol Med. 2011;41(1):85-96.

20. Arshat Z. Adolescents and parental perception of family strength: relation to Malay adolescent emotional and behavioural adjustment. IJHSS. 2013;3(18):163-8.

21. Meinck F, Cluver LDC, Orkin FM, Kuo C, Sharma AD, Hensels IS, et al. Pathways from family disadvantage via abusive parenting and caregiver mental health to adolescent health risks in South Africa. J Adolesc Health. 2017;60(1):57-64.

22. Alamanda KR, Susanti Y, Fitriyana S. Gambaran tingkat kecemasan mahasiswa tingkat IV dalam menghadapi ujian objective structured clinical examination. Prosiding Pendidikan Dokter. 2018;4(1):56-63.

23. Nurhayati E, Fitriyana S. Determinan kesehatan dalam perspektif Islam: studi pendahuluan. JIKS. 2020;2(1):52-6.

24. Nurhayati E, Rathomi HS, Fitriyana S, Ibnusantosa RG.Aremotetraining ofmaternal knowledge and children health center: a multi-user application implementation. J Phys Conf Seri. 2020;1469:012059.

25. Stadler C, Feifel J, Rohrmann S, Vermeiren R, Poustka F. Peer-victimization and mental health problems in adolescents: are parental and school support protective? Child Psychiatry Hum Dev. 2010;41(4):371-86. 